\title{
Mané-Katz: Jewishness and Modernity
}

Svetlana Reingold

Mané-Katz Museum, 89 Yafe Nof St., Haifa, Israel

Email: sveta@hms.org.il

This article introduces Emmanuel Mané-Katz (1894-1962), a Jewish artist from Ukraine, who spent most of his life in Paris. The article discusses the problem of Judaism in art, how this problem was seen by the artists belonging to the Jewish School of Paris, and the relationship between Judaism and modernity in art, including Mané-Katz's work.

KEYWORDS: School of Paris, Montparnasse, Jewish identity, modernity in art, Palestine, Haifa

Mané-Katz was one of the prominent artists of the Jewish School of Paris, active in the first half of the twentieth century. Like many of the artists who came to Paris, he became engaged with modern art and its typical themes - landscape, still life, interiors, portraiture, and genre scenes. However, the core of his oeuvre is reserved for his experience of Jewish life.

From the 1920s until his death in 1962, his works consistently depict the Jewish shtetl and its people. These paintings portray Jewish ritual - prayer, reading, and studying the Torah. He paints yeshiva students, a rabbi immersed in contemplation, the Rejoicing of the Law (Simchat Torah), Hassidic dance and song, Jewish weddings, and klezmer musicians. In his paintings, Jewish reality is not only that of everyday life, but of the Torah and prayer, religious dedication and exaltation. The figures in his works embody the traditional Jewish spirit and form a collective portrait, an archetype of Orthodox and Hassidic Judaism.

Mané-Katz's paintings are expressionist in character - an artistic mode of the early twentieth century that emphasizes the emotional power created by manipulations of colour and distortions of form and space. Deriving from great emotional intensity, the expressionist spirit is evident in the painterly elements of his works.

\section{The Question of Jewish Art}

The definition of "Jewish art" and its unique characteristics has preoccupied scholars and critics since the end of the nineteenth century. It was then that Jewish artists first 
appeared on the European art scene. During the nineteenth century, the art history discourse in Europe was tightly linked to nationalism. Jewish identity lacked a clear national or geographic definition and, as a result, this discourse tended to exclude the Jewish historical artistic narrative. Consequently, the recognition of the existence of Jewish art was closely tied to the Jewish national revival.

In this context, the Jewish philosopher Martin Buber attempted to pinpoint the uniqueness of Jewish expression in the field of art, seeking, in particular, to link "Jewish art" to the revival of the Jewish nation. ${ }^{1}$ Buber actively constructed the category of Jewish art, which had not existed before the first decade of the twentieth century. The book Jewish Art, published in Israel some fifty years after Buber's cultural endeavour, outlined the history of this phenomenon according to the chronological model accepted in the field of art history. ${ }^{2}$ The book reflects a yearning for political and cultural legitimacy for the newly established State of Israel. ${ }^{3}$

Over the years, the category of "Jewish art" has been variously defined, interpreted, and criticized. Avram Kampf, for example, argues that the term fails to recognize "the expression of a specific Jewish experience in 20th century art". ${ }^{4}$ Eva Frojmovic shares this position, claiming that Jewish art history does not fit the established models of art history, since it does not represent a differentiated geographic or stylistic element. ${ }^{5}$ Nichols Mizoeff offers a more nuanced view: he characterizes Jewish art as the art of a diaspora, open to different categorizations that move beyond national identity and are manifested in multiple perspectives. ${ }^{6}$ The discussion of Jewish art is closely related to post-modern and post-colonialist discourse, which introduced new cultural issues such as the other in relation to Western history and the tension between centre and periphery. These new approaches lend legitimacy to the study of Jewish art as the art of the "marginalized other"?

\section{The School of Paris}

The wide-ranging discussion of Jewish art during the 1920s and 1930s focuses on the Jewish artists active in Paris in those years. Many Jewish artists, including Mark Chagall, Chaïm Soutine, Chana Orloff, Jules Pascin, and others, arrived in the city during this period and worked there until the beginning of the Nazi occupation. The name "School of Paris" generally indicates modern art created in Paris in the interwar period, but specifically art created in the city by Jewish

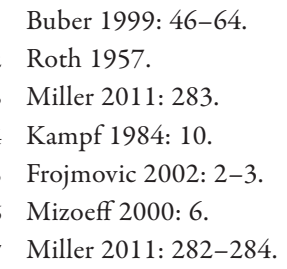


artists. ${ }^{8}$ Mané-Katz moved to Paris in 1913 and was among the group of Jewish artists referred to as the "Circle of Montparnasse"," with reference to the area of the city where they lived and worked.

The enchantment of Jewish artists with Paris was closely linked to the construction of their self-image and self-respect, largely based on their life in the art capital of the world. The city that hosted them became a major element in the crystallization of their new identity. This process recalls Walter Benjamin's conception of the city as the definitive expression of modernity, shaping the experiences and the worldview of anyone living in it. Indeed, familiarity with the material reality of Paris was widely seen as a milestone on the way to becoming a "modern artist". For the contemporary artist, the locus of creativity could only be the capital city of modern art. Furthermore, one specific quarter - Montparnasse - was the accepted centre of the Parisian art scene.

The transition of the artistic and cultural life of Paris to Montparnasse has been studied in depth. ${ }^{10}$ Seeing their life in Montparnasse as an essential factor in becoming modern artists, the city's Jewish artists participated fully in this development. In 1914, the poet Guillaume Apollinaire wrote: "Nowadays the real artists are to be found in Montparnasse... What a fine country that is, where the whole sky is for us to enjoy, a country of fresh air and café terraces" ${ }^{11}$ In his memoir, Mané-Katz expresses a similar sentiment from the period when he was still experimenting with the modernist style: "In those days I never wandered around Montparnasse. I was scared to do so because I didn't want to become a modern artist". 12

The attachment to Paris is central in the debate surrounding the concept of "modernity" with reference to the tension between "here" and "there". The assembly of Jewish artists in Paris is closely connected to the manner in which the city ("there", from the perspective of the Eastern European Jewish shtetl) was imagined as the cultural centre of classical Europe, sublime yet remote: "There is the aesthetic, the great culture of the West. There, materials have souls and meaning, the wine is blood, bread is the body, the cross is fate". ${ }^{13}$

This contrasts sharply with the periphery, making the artist's odyssey to Paris a lifechanging event, with the "pre-Paris" reality differing sharply, unrecognizably, from the post-transitional, Parisian one. In this context, Sarit Shapira discusses the concept of wandering as endemic to the Jewish myth. According to her, wandering through

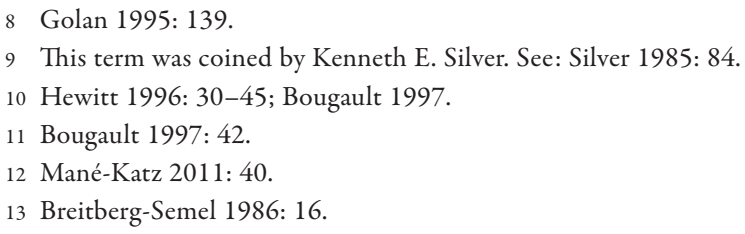


unknown spaces means abandoning the sense of "home", so that movement becomes deliberate and has meaning and limits. Wanderlust is a staple of romantic literature, leading the protagonist on a journey through unknown lands in search of a longedfor place, free from the restrictions of law and order. ${ }^{14}$ For Jewish artists, Paris was the "centre" and a stronghold of freedom, as opposed to the "periphery", where freedom was absent. This is evident in Chagall's memoir: "I arrived [in Paris] as if borne by fate, with all my dreams and ideas. My every desire was fulfilled when I alighted from the train to find the light and liberty I have never encountered anywhere else". ${ }^{15}$

\section{The Jewish Artist and Modernism}

The basic premise of twentieth-century Jewish art is the dichotomy between art and religion. David Sperber suggests that modern Jewish art has its roots in the rebellion of the enlightened Jewish world against its classical heritage. ${ }^{16}$ Gideon Ofrat adds that the yeshiva rebels and the dissidents from Talmudic schools were attracted to the statue of Apollo, preferring the French Master to the Jewish Rabbi, and Western art to the old spiritual wisdom of the Jewish tradition. ${ }^{17}$

Yet the "death of God" at the turn of the twentieth century did not quench the thirst for metaphysical elements in modern art, including Jewish art. If anything, the tension between religion and art was conducive to a restless search for the meaning of the greatest metaphysical paradigms, with modern artists seeking new ways of seeing the world. A number of artists of the Jewish School of Paris - the emergence of which constituted a major event in the history of Jewish art - consistently addressed these issues in their works.

Although Mané-Katz focused on Jewish ritual, the departure from the traditionalistreligious artistic approach is evident in his works, as well as in the oeuvre of many other Jewish artists active in Paris, where they were exposed to a world entirely different from the one they had known in their countries of origin. Arthur Cohen describes these artists' growing awareness of the difference between the Western European discourse concerning the nature of Jewish art, and the art discourse engaged in by artists and intellectuals from the East. ${ }^{18}$ In Eastern Europe, an entire generation of artists and intellectuals was preoccupied with the identity and future of national Jewish art. ${ }^{19}$ In the relaxed atmosphere of Paris, art based on ethnic and national sentiment no longer seemed viable. State-sanctioned

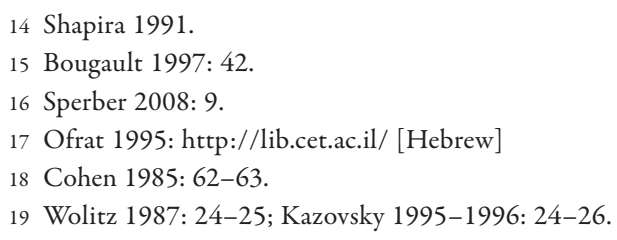


anti-Semitism did not exist in tolerant Paris at least until the 1930s, allowing artists from any ethnic background to creatively express themselves. The urge to belong to the Parisian art scene thus induced most Jewish artists to detach themselves from their Jewish identity, ${ }^{20}$ aspiring to leave an artistic, rather than a Jewish, imprint in the art world. Consequently, Jewish artists were inclined to follow normative styles and typical modernist themes, such as landscapes, still lifes, interiors, and portraiture. ${ }^{21}$

Religious, mythological, and historical themes were regarded as obsolete and "un-modern". Thus, Mané-Katz's interest in these themes was considered "outside the frame." ${ }^{22}$ After his first visit to Palestine in 1928, he created biblical images and representations of his ancestral history, as well as the living reality of the Zionist enterprise. For him, the grandeur of the Middle East evoked scenes from his biblical heritage. In Mané-Katz's works, the resemblance between biblical and rabbinical figures is apparent: even the shepherd playing his flute is reminiscent of a traditional Jew. Mané-Katz linked the Jews of the Diaspora with the ancient Hebrews, the biblical patriarchs, and Jewish leaders throughout the ages. ${ }^{23}$

Initially, these subjects reflected the joy and optimism of the renewed Hebrew culture in Mandatory Palestine. All this changed in the 1940s, when many artists of the School of Paris fled to America from the Nazi occupation..$^{24}$ Apart from ManéKatz, this group included such famous artists as Marc Chagall, Jacques Lipchitz, Ossip Zadkine, Nahum Aronson, Max Band, Eugene Berman, Joseph Floch, Eric Isenburger, and Arthur Kaufmann. ${ }^{25}$

From this time forward and in the aftermath of World War II, Mané-Katz created many works that expressed his concerns regarding the existential danger threatening the Jews of Europe. His paintings on the subject of the Holocaust are usually mediated by conceptual and symbolic elements. Images of prayer and ritual also appear in these works, though they convey different messages and atmospheres. These pieces often juxtapose images of faith and devotion with a call for action and revolt. Mané-Katz witnessed the destruction of his Jewish birthplace, and his works expressed a profound feeling of shock. After the disastrous events of the Holocaust, his depictions of Jewish life in Europe revalidated that age-old tradition, serving as a commemoration of the communal life and a spiritual heritage that was nearly destroyed.

Mané-Katz was also involved in the Israeli art scene: he visited the country frequently, exhibited in local museums, and received warm reviews. His connections

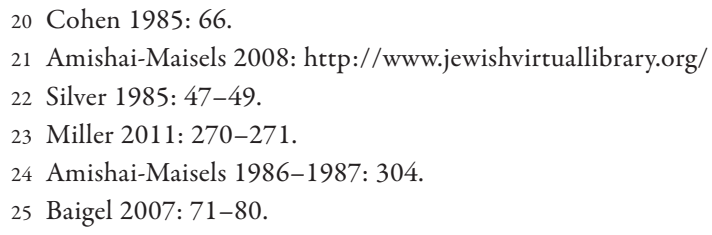


and engagement with Israeli life and culture were part of his extensive activity in the global network of Jewish artists and intellectuals.

Throughout his career, Mané-Katz explored his Judaism, declaring: "I am a Jewish artist and I am proud to bear this title". ${ }^{26}$ Jewish themes inspired his artistic vitality, without detracting from his aspiration to be a modern artist. In his works, the Jewish world is inseparable from contemporary life and modern themes. Although they may seem to be contradictory interests, Jewishness and modernity are interwoven in his oeuvre. ${ }^{27}$

\section{Mané-Katz: Milestones}

1894 Born on 5 June in Kremenchuk, Ukraine, to a traditional and povertystricken Jewish family. His father was the beadle of the synagogue. Mané-Katz studied in a heder and a yeshiva until the age of 16 .

1910-1913 Studies at the Kiev Art School

1913 Arrives in Paris, studies at the École des Beaux-Arts, in the studio of Fernand Cormon

1914 World War I breaks out; visits London on his way back to Russia

1915 Studies at the New Art Workshop founded by Princess Gagarina, Petrograd

1917 Returns to Kremenchuk at the outbreak of the Russian Revolution; appointed a professor at the School of Arts and Crafts, Kharkov Marries Esther (Stera) Pikelna (divorced in 1932)

1928 First visit to Palestine, Egypt, and Syria. Visits Israel frequently in the years that follow

1939 Escapes from Paris to America at the outbreak of World War II. Lives in New York

1945 Returns to Paris, rents a studio in Montparnasse. In the following years he travels widely and exhibits in Paris, Brazil, Geneva, London, New York, Los Angeles, Montreal, Sao Paolo, Tokyo, Johannesburg, Jerusalem, Tel Aviv, Haifa, and elsewhere 
1948 Arrives in Israel during the War of Independence and holds a oneman exhibition at the Tel Aviv Museum

1951 Named Chevalier de la Légion d'Honneur (Knight of the Legion of Honour) by the French Government for his artistic activities

1958 Receives a house on Yafe Nof Road from the Haifa Municipality, later to become a museum containing his works and art collection

1962 Dies on 9 September after an illness and is buried in Haifa

1977 The Mané-Katz Museum is opened to the public

Received 4 October 2017

Accepted 25 April 2020

\section{Bibliography}

1. Aimot, J.-M. Mané-Katz. Paris: Marcel Seheur, 1933.

2. Amishai-Maisels, Z. Ben Shahn and the Problem of Jewish Identity. Ars Judaica, 12-13 (1986-1987): 304-319.

3. Amishai-Maisels, Z. Modern Jewish Art. Encyclopaedia Judaica, 2008. http://www.jewishvirtuallibrary.org/

4. Baigel, M. Jewish Art in America: An Introduction. Lanham, MD: Rowman \& Littlefield, 2007: 71-80.

5. Bougault, V. Paris-Montparnasse: The Heyday of Modern Art, 1910-1940. Paris: Terrail, 1997.

6. Breitberg-Semel, S. The Want of Matter: A Quality in Israeli Art. Exhibition catalogue. Tel Aviv: Tel Aviv Museum of Art, 1986.

7. Buber, M. Address on Jewish Art. The First Buber: Youthful Zionist Writings. Ed. Gilya G. Schmidt. Syracuse, New York: Syracuse University Press, 1999: 46-64.

8. Cohen, A. A. From Eastern Europe to Paris and Beyond. The Circle of Montparnasse: Jewish Artists in Paris, 1905-1940. Exhibition catalogue. Ed. Kenneth E. Silver, Romy Golan. New York: The Jewish Museum, 1985: 12-59.

9. Frojmovic, E. Buber in Basel, Schlosser in Sarajevo, Wischnitzer in Weimar: The Politics of Writing about Medieval Jewish Art. Imagining the Self, Imagining the Other: Visual Representation and Jewish-Christian Dynamics in the Middle Ages and Early Modern Period. Ed. Eva Frojmovic. Leiden: Brill, 2002: 8-19.

10. Golan, R. École Française vs. École de Paris. The Circle of Montparnasse: Jewish Artists in Paris, 1905-1940. Exhibition catalogue. Ed. Kenneth E. Silver, Romy Golan. New York: The Jewish Museum, 1985: 80-87.

11. Golan, R. Modernity and Nostalgia: Art and Politics in France between the Wars. New Haven and London: Yale UP, 1995.

12. Hewitt, N. Shifting Cultural Centres in Twentieth-Century Paris. Parisian Fields. Ed. Michael Sheringham. London: Reaktion Books, 1996: 30-45.

13. Jewish Art. Ed. Cecil Roth. Tel Aviv: Massadah, 1957.

14. Kampf, A. The Jewish Experience in the Art of the Twentieth Century. New York: Bergin \& Garvey, 1984.

15. Kazovsky, H. Jewish Artists in Russia at the Turn of the Century: Issues of National Self-Identification in Art. Jewish Art, 21/22 (1995-1996): 20-39.

16. Mané-Katz, Memories (Paris). Mané-Katz, Issachar Ryback: Encounters. Exhibition catalogue. Ed. Noa Tarshish. Haifa: Mané-Katz Museum, 1993.

17. Mané-Katz: Ukraine, Paris, Eretz Israel. Ed. Noa Tarshish. Haifa: Mané-Katz Museum, 2011.

18. Diaspora and Visual Culture: Representing Africans and Jews. Ed. Nicholas Mirzoeff. London: Routledge, 2000. 
19. Ofrat, G. Israeli Art and Jewish Tradition. Mahanaim, v. 11 (1995: June). http://lib.cet.ac.il/

20. Shapira, S. Wanderers' Routes: Emigration, Journeys and Transitions in Contemporary Israeli Art. Exhibition catalogue. Jerusalem: The Israel Museum, 1991.

21. Silver, K. E. The Circle of Montparnasse: Jewish Artists in Paris. The Circle of Montparnasse: Jewish Artists in Paris, 1905-1940. Exhibition catalogue. Ed. Kenneth E. Silver, Romy Golan. New York: The Jewish Museum, 1985: 12-59.

22. Sperber, D. Broken Vessels: Deconstructive Aspects in Contemporary Jewish Art. Exhibition Catalogue. Tel Aviv: Bar Ilan University, 2008.

23. Wolitz, S. L. Jewish National Art in Russia. Tradition and Revolution: The Jewish Renaissance in Russian Avant-Garde Art, 1912-1928. Ed. Ruth Apter-Gabriel. Jerusalem: The Israel Museum, 1987: 21-43.

Svetlana Reingold

\section{Mané-Katzas: žydiškumas ir modernumas}

\section{Santrauka}

Straipsnyje analizuojami iš Ukrainos kilusio žydų dailininko Mané-Katzo (1894-1962) kūrybos bruožai, žydiškų temų ir modernumo santykis jo mene. Nuo 1913 m. Mané-Katzas buvo glaudžiai susijęs su Paryžiaus dailès mokykla, kuri straipsnyje pristatoma kaip Paryžiaus žydų mokykla. Nagrinejjama žydiško identiteto problema mene apskritai, sąsajos su Monparnaso dailininkų kūryba, pateikiamos šią problemą tyrinèjusių autorių mintys ir pastebejjimai. Vakarų ir Rytų Europos žydai skirtingai perteikia žydiškumo sampratą kūryboje. Požiūriu į žydiškumą taip pat išsiskyrè religingi žydai tradicionalistai ir modernūs sionistai, kurių siekiai buvo nukreipti ị naujo kūrimą. Paryžius neišvengiamai turèjo ịtakos dailininkų kūrybai siekiant modernumo, neretai žydiškų temų buvo vengiama kaip „nemadingų“. Tą tvirtino ir Mané-Katzas, bet tik iki tol, kol pats neapsilankẻ Palestinoje, o atkūrus Izraelio valstybę, ir apsigyveno joje. Jo paveikslų siužetai tapo beveik neatsiejami nuo žydiškų temų, o meninès išraiškos priemonès - nuo perteikiamos žydiškos dvasios, netgi vaizduojant kasdienius buitinius motyvus. Taigi Mané-Katzas savo kūryboje sugebejo suderinti abu šiuos elementus - žydiškumą ir modernumą. RAKTAŽODŽIAI: Paryžiaus dailès mokykla, Monparnasas, žydiškas identitas, modernumas mene, Palestina, Haifa 